\title{
‡USGS
}

science for a changing world

Potential Effects of Climate Changg on Snail Kites (Rostrhamus socighilis plumbeus) in Florida

Chapter $A$ of

*'. Effects of Climate Change on Fish and Wfildife Species in the United States
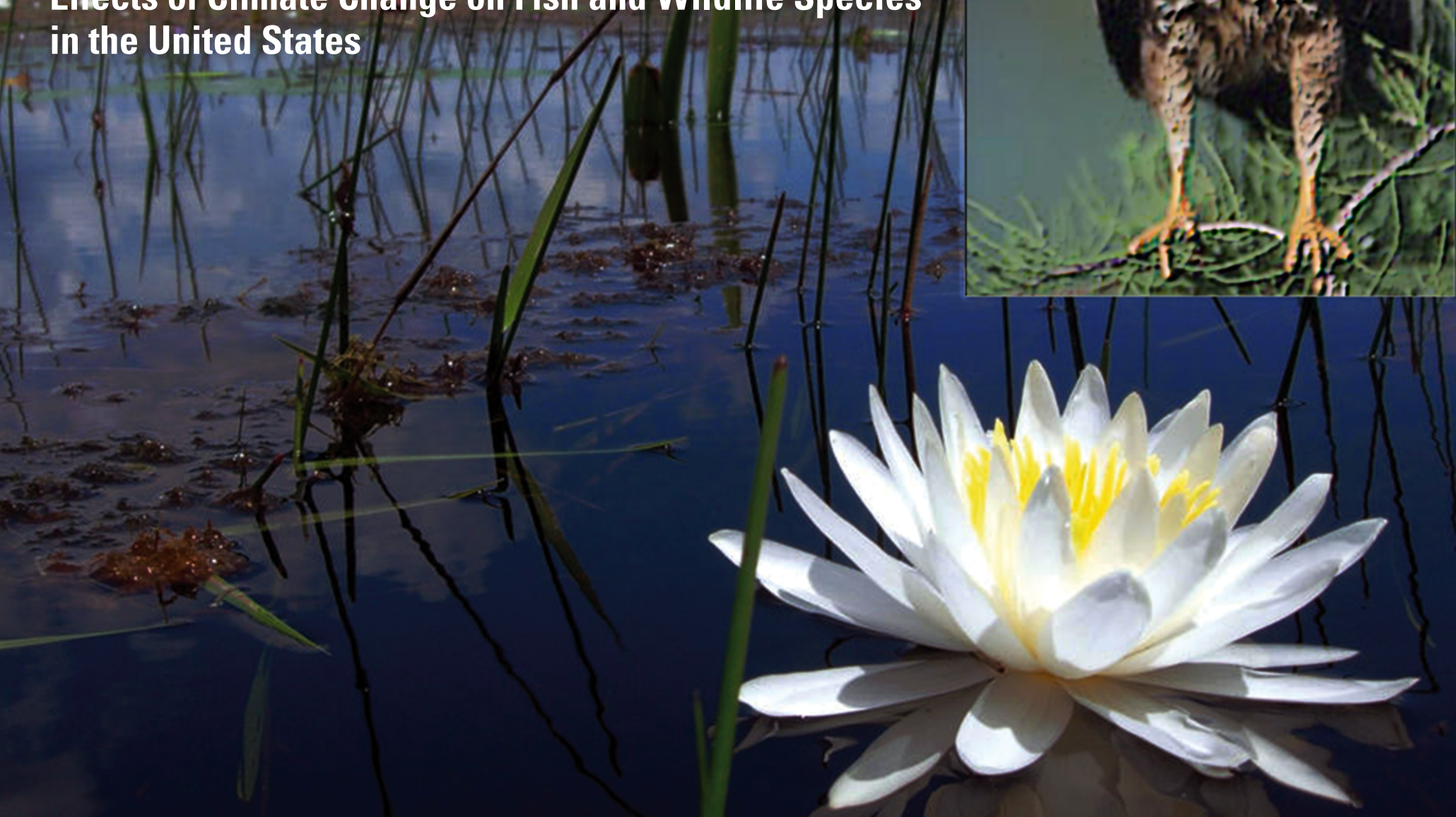

Open-File Report 2021-1104-A

U.S. Department of the Interior

U.S. Geological Survey 
Front cover. Background image, photograph of Florida Everglades, U.S. Geological Survey Florida Cooperative Fish and Wildlife Research Unit, U.S. Geological Survey, 2010 (approx.); Snail Kite image, photograph by U.S. Geological Survey South Atlantic Water Science Center, October 3, 2016. 


\section{Potential Effects of Climate Change on Snail Kites (Rostrhamus sociabilis plumbeus) in Florida}

By Marta P. Lyons, Olivia E. LeDee, and Ryan Boyles

Chapter A of Effects of Climate Change on Fish and Wildlife Species in the United States

Open-File Report 2021-1104-A 


\section{U.S. Geological Survey, Reston, Virginia: 2022}

For more information on the USGS - the Federal source for science about the Earth, its natural and living resources, natural hazards, and the environment—visit https://www.usgs.gov or call 1-888-ASK-USGS.

For an overview of USGS information products, including maps, imagery, and publications, visit https://store.usgs.gov/.

Any use of trade, firm, or product names is for descriptive purposes only and does not imply endorsement by the U.S. Government.

Although this information product, for the most part, is in the public domain, it also may contain copyrighted materials as noted in the text. Permission to reproduce copyrighted items must be secured from the copyright owner.

Suggested citation:

Lyons, M.P., LeDee, 0.E., and Boyles, R., 2022, Potential effects of climate change on snail kites (Rostrhamus sociabilis plumbeus) in Florida: U.S. Geological Survey Open-File Report 2021-1104-A, 12 p., https://doi.org/10.3133/ofr20211104A.

ISSN 2331-1258 (online) 


\section{Acknowledgments}

We thank Tyler Beck, Robert Fletcher, Brian Jeffery, Josh Cullen, Caroline Poli, and Heather Tipton for providing valuable insight on snail kite ecology. Josh Cullen, Tyler Beck, Robert Fletcher, Kathryn Smith, Heather Tipton, and Victoria Garcia provided helpful comments on an earlier draft.

We would like to thank Lisa Webb, Lindsey Thurman, and Michelle Staudinger of the U.S. Geological Survey for their edits and comments to this chapter. This research was funded by the U.S. Geological Survey Midwest Climate Adaptation Science Center and the Southeast Climate Adaptation Science Center. 



\section{Contents}

Acknowledgments ……...................................................................................................................

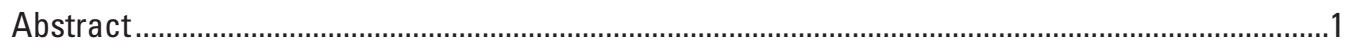

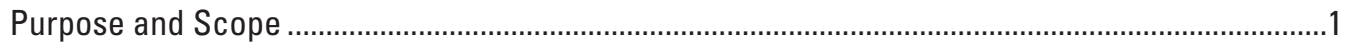

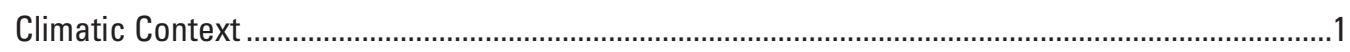

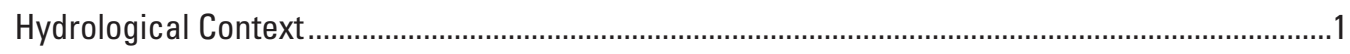

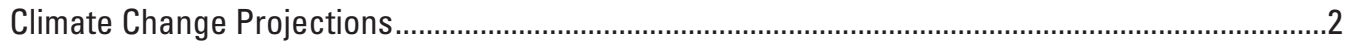

Reproduction and Recruitment ......................................................................................

Dry Conditions Decrease Nest Initiation, Nest Success, and Juvenile Survival .......................3

Heavy Precipitation Events Decrease Nest Survival and Nesting Attempts.............................4

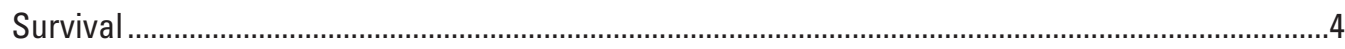

Drought Decreases Adult Survival ...................................................................................

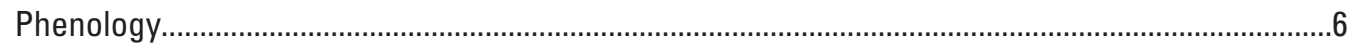

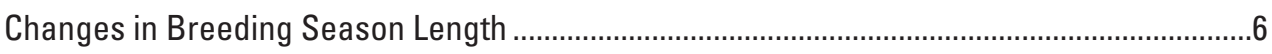

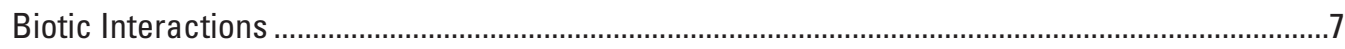

Dry Conditions Decrease Prey Access and Densities ..........................................................

Dry Conditions Increase Depredation .................................................................................

Heavy Precipitation Events Decrease Prey Access and Densities ...........................................

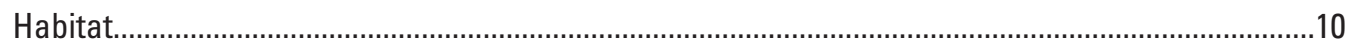

Central Florida Lacustrine Nesting Areas Less Sensitive to Climate Change ........................10

Rising Sea Level and Changing Climate Affect Habitat Suitability in the Everglades.............10

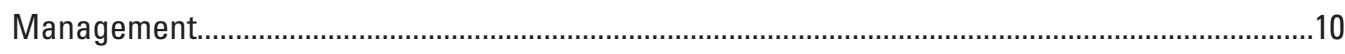

Potential for Water-Management Decisions to Offset or Exacerbate Changes

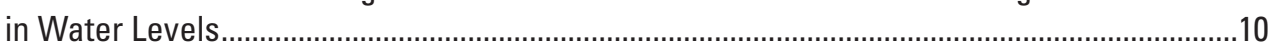

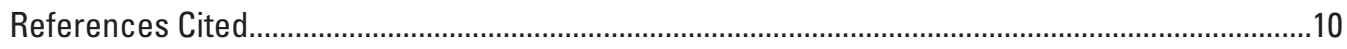

\section{Figures}

1. Map showing rectangular areas used to generate boxplots of future climate projections

2. Boxplots showing projected annual precipitation for four 30 -year time periods from 1971 to 2099 in three areas in central and southern Florida used by nesting snail kites (Rostrhamus sociabilis plumbeus)

3. Boxplots showing projected seasonal precipitation for four 30-year time periods from 1971 to 2099 in three areas in central and southern Florida used by nesting snail kites (Rostrhamus sociabilis plumbeus)

4. Boxplots showing projected annual potential evapotranspiration for four 30-year time periods from 1971 to 2099 in three areas in central and southern Florida used by nesting snail kites (Rostrhamus sociabilis plumbeus) ...............................

5. Graphs showing summary of historical average monthly temperature and precipitation normals from 1991 to 2020 for three areas in central and southern Florida used by nesting snail kites (Rostrhamus sociabilis plumbeus)......

6. Boxplots showing projected average temperature in winter and spring for four 30-year time periods from 1971 to 2099 in three areas in central and southern Florida used by nesting snail kites (Rostrhamus sociabilis plumbeus) 
7. Boxplots showing projected seasonal potential evapotranspiration for four 30-year time periods from 1971 to 2099 in three areas in central and southern Florida used by nesting snail kites (Rostrhamus sociabilis plumbeus)

\section{Tables}

1. Direct and indirect effects of climate on snail kites (Rostrhamus sociabilis plumbeus) in Florida

\section{Conversion Factors}

\begin{tabular}{|c|c|c|}
\hline Multiply & By & To obtain \\
\hline \multicolumn{3}{|c|}{ Length } \\
\hline centimeter (cm) & 0.3937 & inch (in.) \\
\hline millimeter (mm) & 0.03937 & inh (in.) \\
\hline meter (m) & 3.281 & foot (ft) \\
\hline \multicolumn{3}{|c|}{ Area } \\
\hline square meter $\left(\mathrm{m}^{2}\right)$ & 0.0002471 & acre \\
\hline
\end{tabular}

Temperature in degrees Celsius $\left({ }^{\circ} \mathrm{C}\right)$ may be converted to degrees Fahrenheit $\left({ }^{\circ} \mathrm{F}\right)$ as follows:

$$
{ }^{\circ} \mathrm{F}=\left(1.8 \times{ }^{\circ} \mathrm{C}\right)+32 .
$$

\section{Abbreviations}

GCM global climate model

MACAv2 Multivariate Adaptative Constructed Analogs version 2

RCP4.5 representative concentration pathway 4.5

RCP8.5 representative concentration pathway 8.5 


\title{
Potential Effects of Climate Change on Snail Kites (Rostrhamus sociabilis plumbeus) in Florida
}

\author{
By Marta P. Lyons, Olivia E. LeDee, and Ryan Boyles
}

Abstract

The snail kite (Rostrhamus sociabilis plumbeus), an endangered, wetland-dependent raptor, is highly sensitive to changes in hydrology. Climate-driven changes in water level will likely affect snail kite populations - altering reproductive success and survival rates. Identifying the mechanisms mediating the direct and indirect effects of climate on snail kite populations and the range of future climate conditions is important to the conservation of this species. When water levels are low, snail kite nest initiation and nest success decrease owing to decreased availability of their primary prey applesnails (Pomacea spp.), unstable nesting sites, and increased predator access. Dry events also lead to decreased adult and juvenile survival. In the next 80 years, temperatures and potential evapotranspiration are projected to increase in central and southern Florida. Although future precipitation volume is more uncertain, increased temperatures and evaporative loss may lead to increased frequency, duration, and severity of lowwater events. Additionally, rapidly rising water levels have adverse effects on snail kite reproductive success - destroying nests, preventing access to apple snails, and reducing apple snail productivity. Finally, it is likely that future climate will favor more frequent dry conditions and extreme heavy rainfall events, both of which are directly linked to decreased reproductive success and survival. The potential effects of climate change may be buffered by the availability of alternative prey (non-native applesnails) that are more tolerant of anticipated conditions. In highly controlled southern Florida waterbodies, regional water-management decisions may buffer or exacerbate waterbody accession and recession rates.

\section{Purpose and Scope}

The purpose of this report is to provide a rapid qualitative overview of the direct and indirect effect of climate change to snail kite life cycle and habitat based on the best available science. This report focuses on snail kite populations and climate change within the state of Florida.

\section{Climatic Context}

Snail kites (Rostrhamus sociabilis plumbeus) occupy habitat in southern Florida with a humid subtropical climate. The cool season (December-February) is associated with dry conditions with seasonal precipitation totals of about 150 millimeters ( $\mathrm{mm})$, maximum temperatures that average near 25 degrees Celsius $\left({ }^{\circ} \mathrm{C}\right)$, and minimum temperatures that average near $10^{\circ} \mathrm{C}$. Freeze events (temperatures less than or equal to $0^{\circ} \mathrm{C}$ ) are infrequent near Lake Okeechobee and extremely rare farther south in the Everglades (fig. 1). The warm season (June-August) experiences regular convective rainfall with seasonal precipitation totals of about $600 \mathrm{~mm}$, maximum temperatures that average near $32{ }^{\circ} \mathrm{C}$, and average minimum temperatures of $22^{\circ} \mathrm{C}$. The vernal and autumnal seasons are transitional periods between warmer/wetter and cooler/drier seasons. Temperatures are heavily moderated (during the time of year and for each specific location) by proximity to the Gulf of Mexico and tropical Atlantic Ocean. More details on the general climate of the region are provided in Runkle and others (2017) and Winsberg (2021).

\section{Hydrological Context}

The water flow, water level, inundation periods, and general hydrology of south Florida are heavily managed to balance the competing demands for flood control, water supply, water quality, and ecosystem health and function. Federal, State, and local agencies manage a complex system of canals, levees, pumps, weirs, and culverts. Moreover, one of the world's largest ecosystem restoration efforts is underway to restore the Everglades region. Details on the water management and hydrology of this region is described by Qiu and Ciuca (2021). Climate variability from year-to-year and longer-term climate trends affect the water input and evaporative loss across this region. However, the management of water through control structures can dramatically dampen or amplify climate-driven variations (Mirchi and others, 2018). 


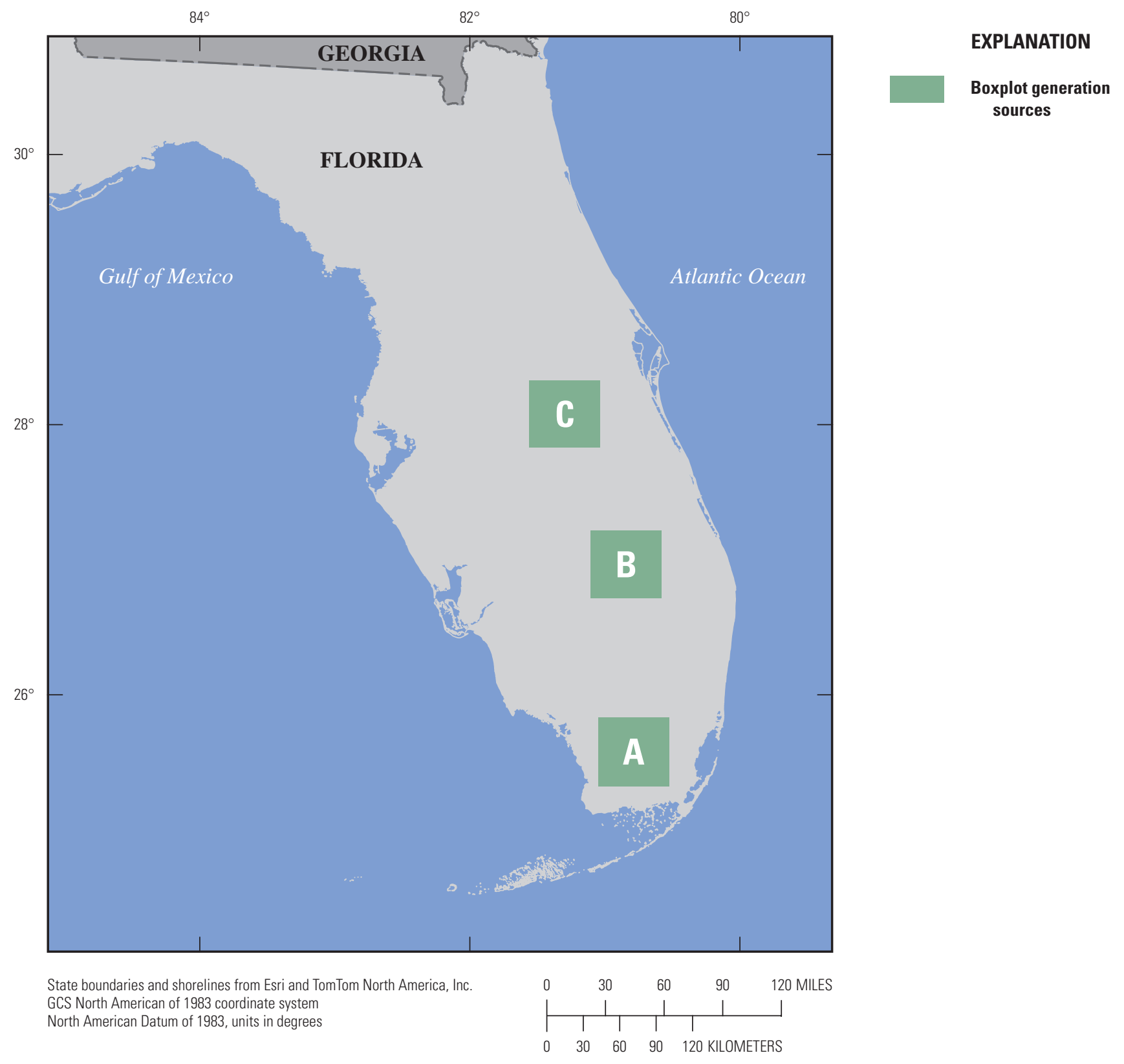

Figure 1. Rectangular areas used to generate boxplots of future climate projections. $A$, Everglades National Park. $B$, Lake Okeechobee. $C$, Kissimmee Chain of Lakes.

The substantial network of hydrological controls in this region provides the ability for resource management agencies to be highly adaptive to changing climate.

\section{Climate Change Projections}

To explore the potent range of future climate changes, we used the latest available downscaled projections for this region based on Intergovernmental Panel on Climate Change Coupled
Model Intercomparison Project Phase 5 (CMIP5) models for two emissions scenarios, a moderate emissions scenario (representative concentration pathway 4.5 [RCP4.5]) and a high emissions scenario (representative concentration pathway 8.5 [RCP8.5]) that are statistically downscaled using Multivariate Adaptative Constructed Analogs version 2 (MACAv2) accessed through https://climatetoolbox.org/ (Abatzoglou and Brown, 2012). MACAv2 uses 20 of the available global climate models (all that have the necessary variables needed for this method) and a multistep constructed analog approach to establish relations between global climate model output 
and historical climate observations, then bias-corrects each climate variable to develop higher resolution and localized projections with approximately 5 kilometers spatial resolution. MACAv2 was chosen because it is widely vetted and used for impact studies, provides adequate spatial resolution to distinguish differences across three habitat zones (Everglades, Lake Okeechobee, and Kissimmee Chain of Lakes), and has been shown to better capture signals in rainfall extremes and frequency as compared to other downscaled products (Wang and others, 2020; Wootten and others, 2021).

\section{Reproduction and Recruitment}

\section{Dry Conditions Decrease Nest Initiation, Nest Success, and Juvenile Survival}

There is substantial evidence that drought, low water depth, and rapid water-level recession correlate with reduced snail kite nest initiation and nest success (table 1). Limited nest initiation and success during dry periods are associated with decreased habitat suitability, unstable nesting substrates, decreased prey availability, and increased nest depredation.

When water levels are low, snail kites nest lower in the littoral zone on nonwoody substrates that are unstable and vulnerable to collapse (Beissinger, 1986; Snyder and others, 1989; Beissinger and Snyder, 2002). Some instances of nest failure, previously attributed to nest collapse, may be the result of depredation (Olbert, 2013). Drier spring seasons after nest initiation may lead to rapid water-level recession, which would endanger nests (Fletcher and others, 2021). During nesting season, low water levels increase the risk of nest desertion and nest failure, owing to food stress on nesting adults from decreased abundance of apple snails, the primary food for snail kites (Snyder and others, 1989). Adult snail kites may renest (Beissinger, 1995), assuming favorable conditions elsewhere (Dreitz and others, 2001), but will exhibit lower nest success (Cattau and others, 2016) and juvenile survival (Fletcher and others, 2020).

When low-water events are localized, snail kites will not select the affected area as a nest site (Dreitz and others, 2001). Movement to new nest sites is energetically expensive and relies on connectivity between waterbodies, making central stepping-stone habitats like Lake Okeechobee critical (Reichert and others, 2021). Based on population models, the negative effects of drought on snail kite populations become apparent when the drought conditions are widespread throughout the range (Beissinger, 1995) and happen more frequently than 4.3 years (Beissinger, 1995; Mooij and others, 2002). Snail kite sensitivity to drought is largely mediated through the availability of their primary prey: applesnails. The aforementioned population models are based on habitats with only Florida applesnails (Pomacea paludosa), which are more sensitive to desiccation than the now common non-native applesnails (Pomacea maculata). After reproductive failure, snail kites are likely to emigrate to a new waterbody; however, dispersal equates to later nest initiation and increased risk for reproductive (Robertson and others, 2017) and recruitment failure (Fletcher and others, 2020).

Owing to increasing temperatures, increased potential evapotranspiration, and limited precipitation, south and central Florida are projected to experience more dry periods in the future. Twenty downscaled global climate model (GCM) projections of annual rainfall in central and southern Florida indicate uncertainty in the total amounts of precipitation projected by the end of the century based on moderate (RCP4.5) and high (RCP8.5) emission pathways. Global climate models do not all agree on the direction of change, with some projecting substantial decreases and others modest increases in

Table 1. Direct and indirect effects of climate on snail kites (Rostrhamus sociabilis plumbeus) in Florida.

[NA, not applicable]

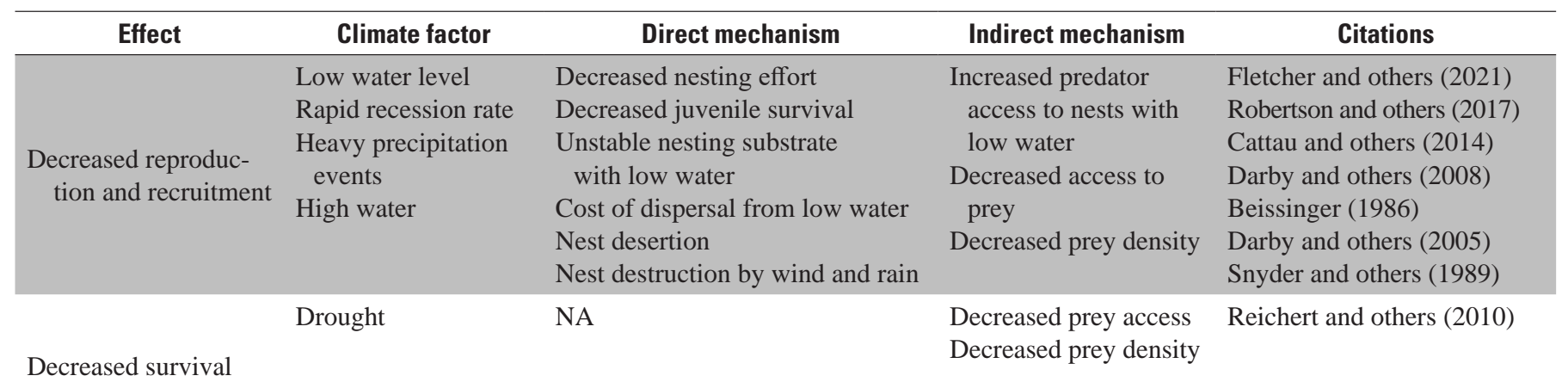

\begin{tabular}{|c|c|c|c|c|}
\hline $\begin{array}{l}\text { Longer breeding } \\
\text { season }\end{array}$ & $\begin{array}{l}\text { Warm spring } \\
\text { Wet summer }\end{array}$ & $\begin{array}{l}\text { Increased risk of nest } \\
\text { flooding/destruction }\end{array}$ & $\begin{array}{l}\text { Reduced prey avail- } \\
\text { ability late in } \\
\text { breeding season }\end{array}$ & $\begin{array}{l}\text { Cattau and others (2016 } \\
\text { Robertson and } \\
\text { others (2017) }\end{array}$ \\
\hline
\end{tabular}


annual precipitation (fig. 2). Seasonally, not all GCMs agree on whether future summers will receive more or less rainfall as compared to the baseline reference from the past three decades. However, more than one-half of the climate models analyzed indicated a decrease in future summer rainfall (June-August) (fig. 3). There is agreement among GCM projections that potential evapotranspiration will continue to increase during the 21st century (fig. 4) primarily owing to increasing temperatures (Reidmiller and others, 2018). If not compensated by seasonal precipitation, this increase in potential evapotranspiration may lead to more severe and more frequent droughts. In the absence of compensatory rainfall or adaptive water management, the region will likely experience an increased frequency of low water levels with likely negative implications for snail kite nest initiation, nest survival, and juvenile survival.

\section{Heavy Precipitation Events Decrease Nest Survival and Nesting Attempts}

Snail kite reproduction is also negatively affected by high and rapidly ascending water levels. Beissinger (1986) determined that in very wet years, one-half of snail kite nests failed before fledging. Similarly, Fletcher and others (2021) determined the probability of nest survival decreased when stage and rate of water-level change exceeded threshold levels, dependent on waterbody. A rapid increase in local water level can directly affect nests, reduce prey access, and reduce future prey populations (that is, lowering snail recruitment) (table 1; Darby and others, 2005).
Climate models project that the frequency of intense storms and rainfall during storm events will continue increasing (Reidmiller and others, 2018). Following the 2017 Hurricane Irma, 55 active nests failed owing to high winds (Fletcher and others, 2018). Heavy rainfall events from slow moving storms are expected to increase in Florida (Reidmiller and others, 2018), which will increase the risk for rapid ascension of water levels and failure owing to exposure.

\section{Survival}

\section{Drought Decreases Adult Survival}

Drought may negatively affect adult survival. During the drought event of 2000-02, adult survival significantly decreased, especially for snail kites more than 13 years in age (Reichert and others, 2010) (table 1). For lakes in central Florida, recession rates are slower and depth does not drop as much as waterbodies in southern Florida. During dry events, when water levels are low in other parts of the distribution, lakes in central Florida may be used in higher numbers. Lakes in central Florida, in addition to being less prone to rapid changes in water levels, also have on average decreased adult survival compared to southern nesting areas (Cattau and others, 2016). Dry periods in southern and central Florida will likely increase in the next 80 years, with increasing temperatures leading to increasing evaporative water loss; these

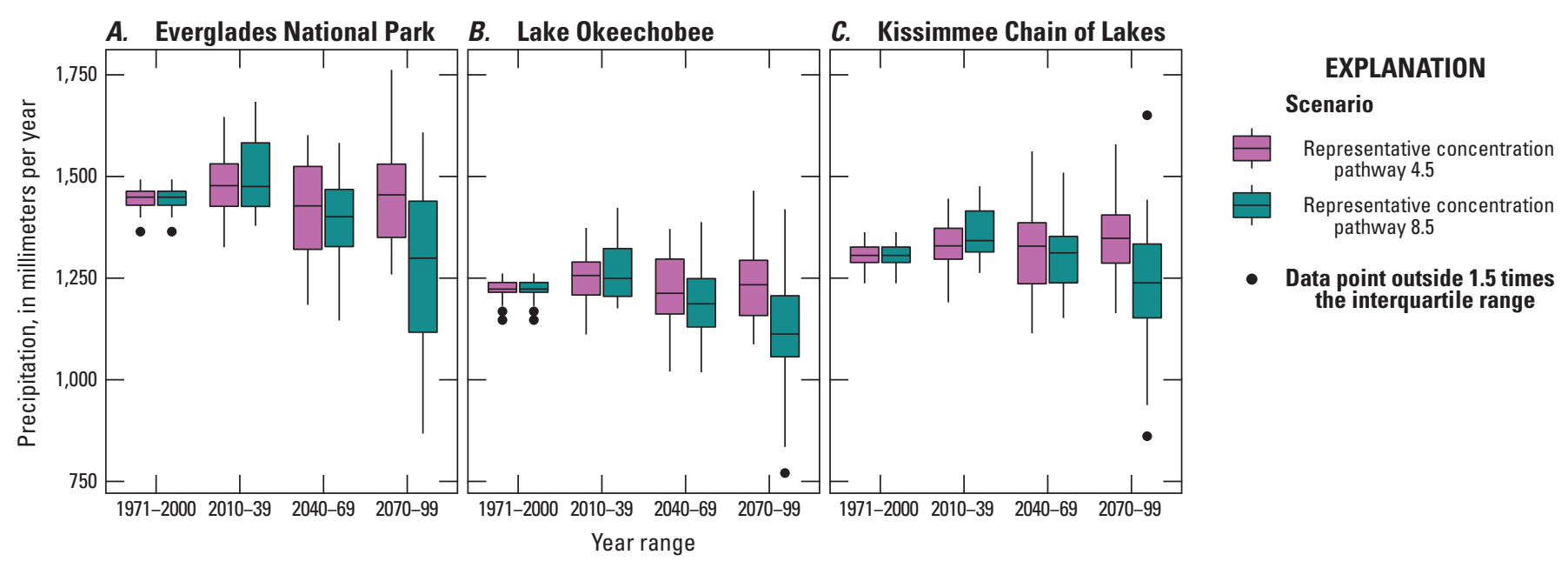

Projected values of 20 global climate models from MACAv2-METDATA (Abatzoglou and Brown, 2012) accessed from Climate Toolbox (Hegewisch and Abatzoglou, undated)

Figure 2. Projected annual precipitation for four 30-year time periods from 1971 to 2099 in three areas in central and southern Florida used by nesting snail kites (Rostrhamus sociabilis plumbeus). A, Everglades National Park. B, Lake Okeechobee. C, Kissimmee Chain of Lakes. Boxplots depict the minimum, first quartile, median, third quartile, and maximum, with outliers beyond 1.5 times the interquartile range depicted as single points. 
A. Everglades National Park B. Lake Okeechobee

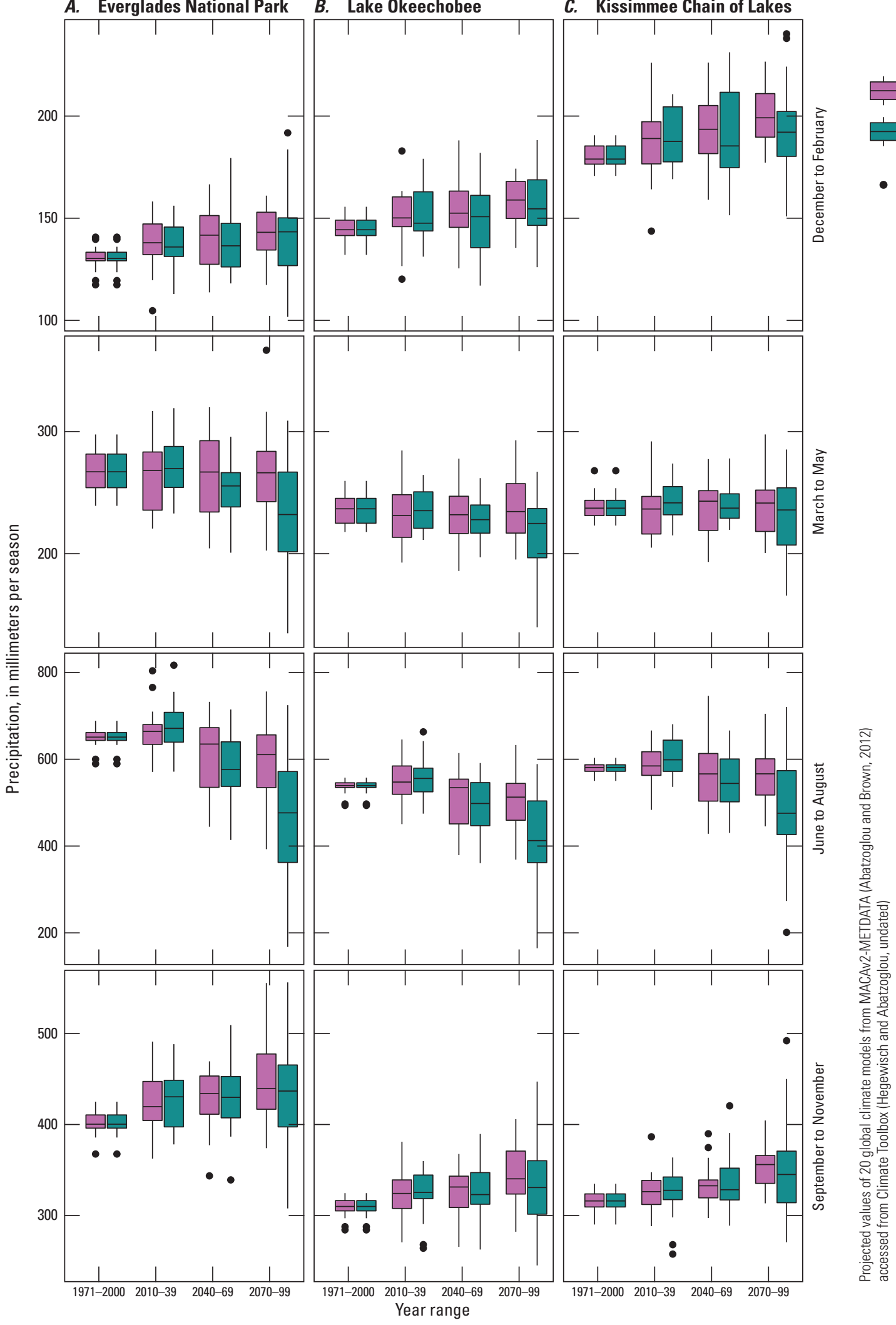

EXPLANATION

Scenario

Representative concentration pathway 4.5

Representative concentration pathway 8.5

Data point outside 1.5 times the interquartile range

Figure 3. Projected seasonal precipitation for four 30-year time periods from 1971 to 2099 in three areas in central and southern Florida used by nesting snail kites (Rostrhamus sociabilis plumbeus). $A$, Everglades National Park. $B$, Lake Okeechobee. $C$, Kissimmee Chain of Lakes. Boxplots depict the minimum, first quartile, median, third quartile, and maximum, with outliers beyond 1.5 times the interquartile range depicted as single points. 


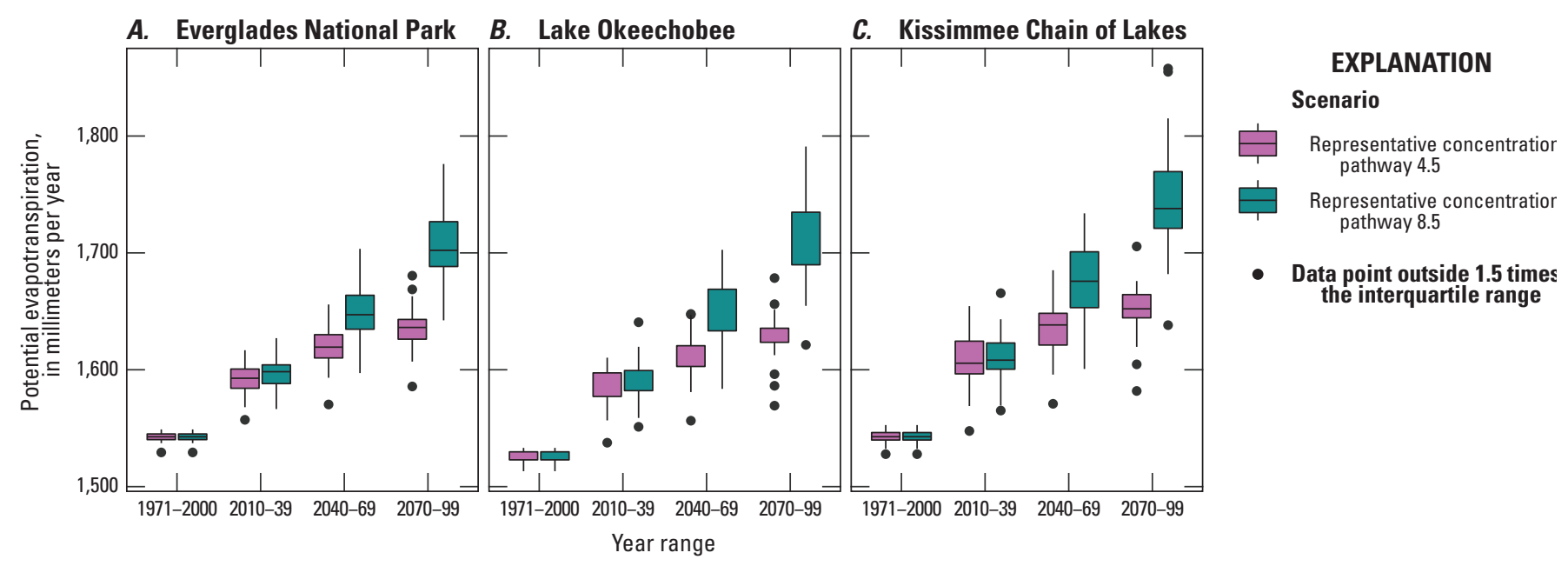

Projected values of 20 global climate models from MACAv2-METDATA (Abatzoglou and Brown, 2012) accessed from Climate Toolbox (Hegewisch and Abatzoglou, undated)

Figure 4. Projected annual potential evapotranspiration for four 30-year time periods from 1971 to 2099 in three areas in central and southern Florida used by nesting snail kites (Rostrhamus sociabilis plumbeus). A, Everglades National Park. B, Lake Okeechobee. $C$, Kissimmee Chain of Lakes. Potential evapotranspiration represents maximum water demand for a well-watered grass surface using Penman-Monteith method (Allen and others, 1998; Abatzoglou, 2013). Boxplots depict the minimum, first quartile, median, third quartile, and maximum, with outliers beyond 1.5 times the interquartile range depicted as single points.

changes, not likely to be compensated by projected precipitation changes, may lead to reduced adult survival during dry periods.

\section{Phenology}

\section{Changes in Breeding Season Length}

For snail kites, breeding season length correlates with seasonal environmental conditions. Nest success and fledgling survival decrease throughout the breeding season (Cattau and others, 2016).

Snail kite breeding season is long but variable, depending on water levels. Nest initiation can start in December and continue for 31 weeks through August (Snyder and others, 1989) but peaks from late February through late April, with the greatest number of active nests in mid-April (Fletcher and others, 2018). During peak breeding season (March and April), average temperatures in central and southern Florida range between $12.4^{\circ} \mathrm{C}$ minimum and $30.6^{\circ} \mathrm{C}$ maximum, and rainfall averages between 53.3 and $78.0 \mathrm{~mm}$ per month (fig. 5). Longer snail kite breeding seasons are correlated with wetter summers and warmer springs (Cattau and others, 2016). Snail kite nests that are initiated later in the breeding season have a lower chance of nest survival (Cattau and others, 2016). In addition, juveniles that fledge from late-season nests have a lower survival rate (Fletcher and others, 2020). Late-season nests experience lower water depths, which corresponds to the lower success rates (Robertson and others, 2017). However, late-season nest success and juvenile survival rates are higher in areas with access to non-native applesnails (Cattau and others, 2016). During favorable conditions, adults will nest multiple times in a year (Beissinger, 1986; Snyder and others, 1989; Beissinger, 1995). Although late-season nests are less successful, they may contribute to population stability or growth.

Since 1979, average spring season temperatures have increased and are projected to continue to increase in the three main regions where snail kites nest: the Everglades, Lake Okeechobee, and the Kissimmee Chain of Lakes (fig. 6). For RCP4.5 and RCP8.5, GCMs do not provide a clear direction on how rainfall might change, and project that summer rainfall totals could increase, remain the same, or decrease (fig. 3; Reidmiller and others, 2018). However, there is agreement among climate models that with projected increases in temperature, potential evapotranspiration will increase (fig. 7), leading to drier summers if not compensated by seasonal rainfall. Although climate models do not agree on wetter conditions during the current breeding season, projected warming is likely to increase breeding season length. 


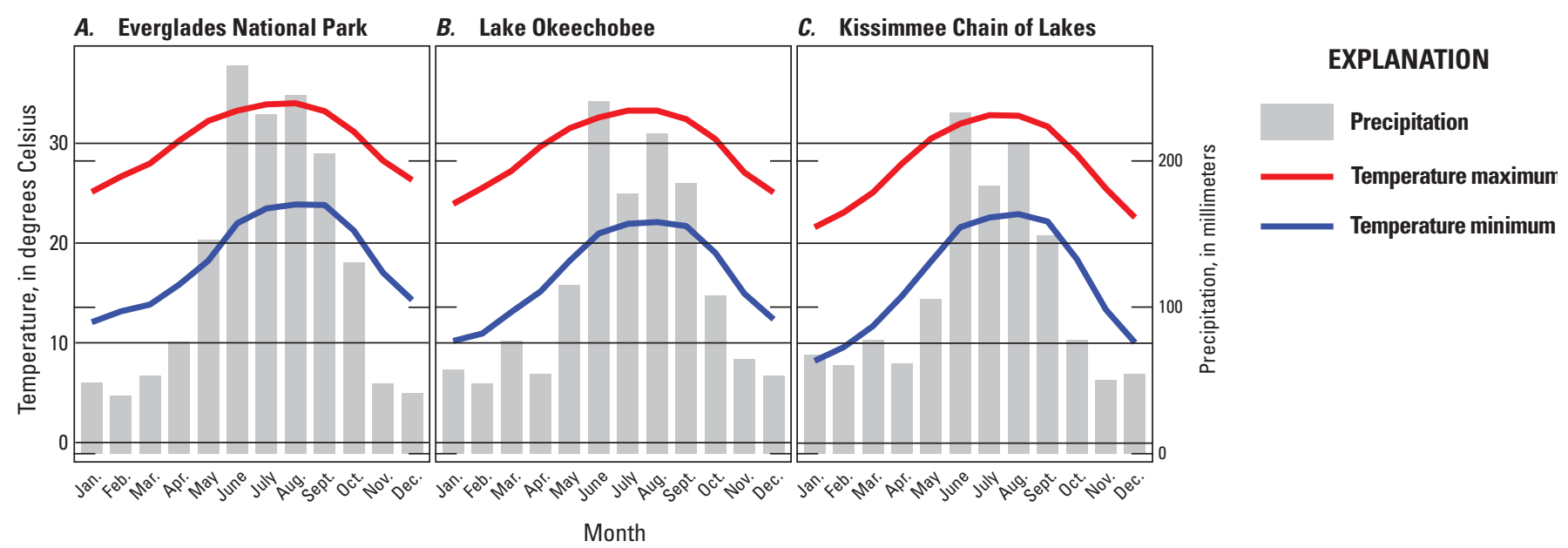

Source: National Oceanic and Atmospheric Administration National Centers for Environmental Information Monthly Climate Normals for 1991 to 2020 (Palecki and others, 2021)

Figure 5. Summary of historical average monthly temperature and precipitation normals from 1991 to 2020 for three areas in central and southern Florida used by nesting snail kites (Rostrhamus sociabilis plumbeus). A, Everglades National Park. B, Lake Okeechobee. C, Kissimmee Chain of Lakes.

\section{Biotic Interactions}

\section{Dry Conditions Decrease Prey Access and Densities}

During dry periods, reductions in snail kite nest initiation and nest success are primarily caused by lack of access to the primary food source, applesnails. Florida applesnails are sensitive to low water levels, which affect snail movement, reproduction, and survival (Darby and others, 2008). Nonnative applesnails, now a common prey item in most of the snail kite's range outside of the Everglades (Cattau and others, 2016), have higher desiccation tolerance than Florida applesnails (Glasheen and others, 2017). However, dry periods will still reduce overall snail reproduction and prey availability to snail kites.

Adult Florida applesnails can withstand low water conditions for several weeks (Darby and others, 2008). When water levels decrease to 10-20 centimeters in depth, Florida applesnails move to deeper water; below 10 centimeters in depth, Florida applesnails cease movement (Darby and others, 2002), becoming less accessible to snail kites. During dry conditions, applesnails will not reproduce, decreasing recruitment and future abundance. Dry-down events can also be fatal to juvenile Florida and non-native applesnails (Darby and others, 2008; Burks and others, 2017). Kushlan (1975) determined that Florida applesnail densities dropped from 0.4 snail per square meter to less than 0.1 snail per square meter the year following a dry-down event. Darby and others (2006) determined that when Florida applesnail density drops below 0.14 snail per square meter, snail kites will not forage at that site. Cattau and others (2014) similarly determined that sites with 0.12 snail per square meter were not occupied by snail kites. The number of snail kites that fledge per nest is positively correlated with Florida applesnail density in a waterbody (Cattau and others, 2014). This correlation is mediated through factors beyond direct food provisioning; when adult snail kites have to travel longer distances to forage for prey, nests are vulnerable to depredation (Olbert, 2013) and the risk of nest desertion by one or both parents increases (Snyder and others, 1989).

Florida applesnail egg production peaks in April-May (Darby and others, 2008). Average temperatures in the three main nesting regions during April and May range between $14.9^{\circ} \mathrm{C}$ minimum and $31.5^{\circ} \mathrm{C}$ maximum, and rainfall averages between 65.0 and $129.1 \mathrm{~mm}$ per month (fig. 5). Non-native applesnail reproductive season appears to last throughout the summer from May to September (Marzolf, 2015; Burks and others, 2017) when average temperatures range between $18.8{ }^{\circ} \mathrm{C}$ minimum and $34.2^{\circ} \mathrm{C}$ maximum, and rainfall averages between 105.9 and $265.4 \mathrm{~mm}$ per month (fig. 5). In the next 80 years, GCMs project increased evapotranspiration in the spring and summer seasons. There is not agreement in the direction of change for precipitation volume between GCMs in the spring season, except in the Everglades under the highest emissions scenario (RCP8.5) and across all regions in the summer under RCP8.5, where 


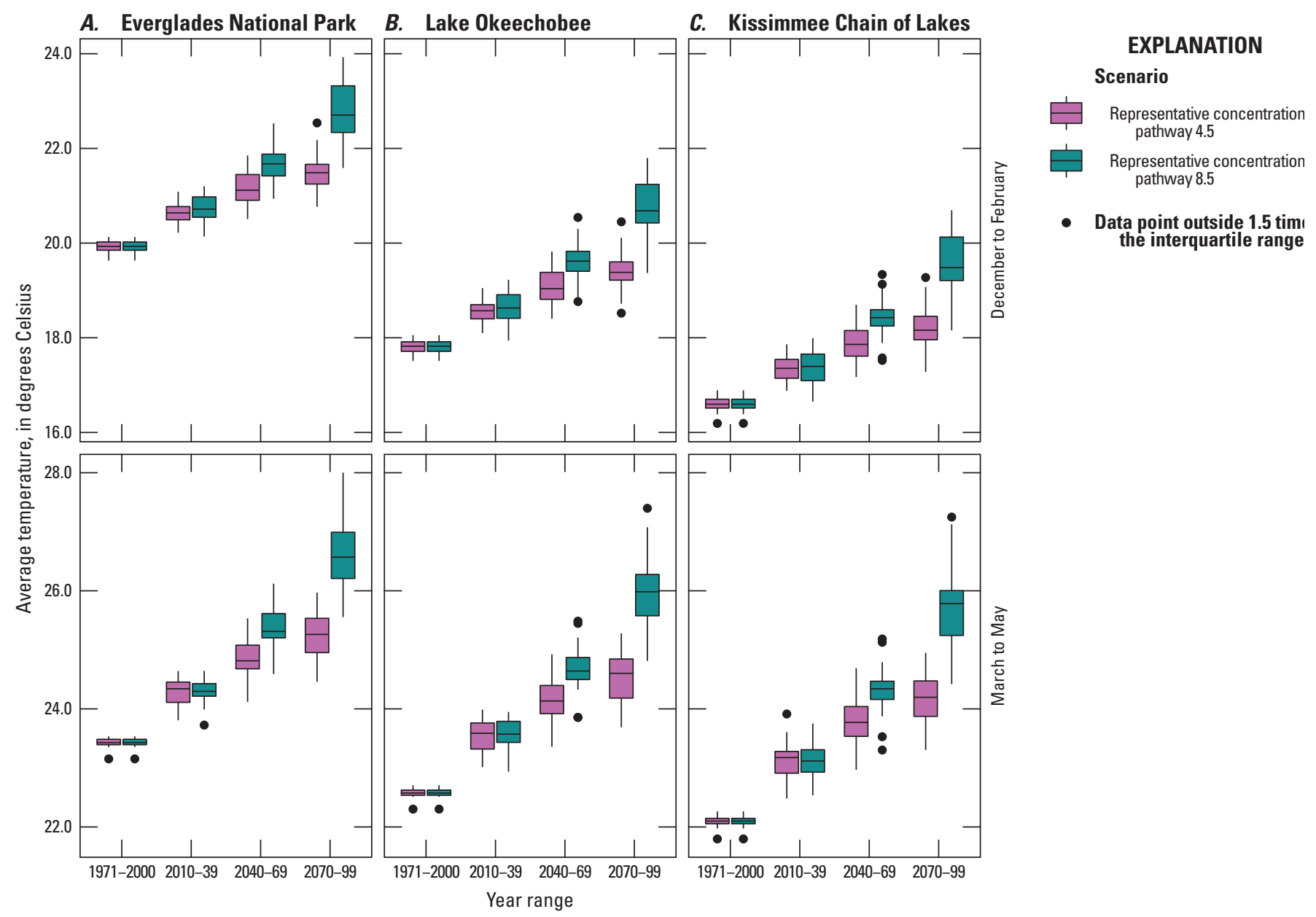

Projected values of 20 global climate models from MACAv2-METDATA (Abatzoglou and Brown, 2012) accessed from Climate Toolbox (Hegewisch and Abatzoglou, undated)

Figure 6. Projected average temperature in winter and spring for four 30-year time periods from 1971 to 2099 in three areas in central and southern Florida used by nesting snail kites (Rostrhamus sociabilis plumbeus). A, Everglades National Park. B, Lake Okeechobee. $C$, Kissimmee Chain of Lakes. Boxplots depict the minimum, first quartile, median, third quartile, and maximum, with outliers beyond 1.5 times the interquartile range depicted as single points.

precipitation volume is projected to decrease by the end of the century (fig. 3). Climate projections indicate an increase in the frequency of low water levels, with negative implications for snail kite foraging, nest initiation, and nest success; whether future low-water events affect applesnail densities will depend on the timing in relation to applesnail life cycles.

\section{Dry Conditions Increase Depredation}

Low water conditions also increase nest depredation. If low water conditions develop after a nest is initiated, predators such as rat snakes and raccoons may have greater access to the nest (Beissinger, 1986; Snyder and others, 1989). If prey is scarce, adult snail kites will spend more time foraging, leaving nests more vulnerable to depredation (Olbert, 2013). Based on GCM projections, it is likely that future climate will favor more dry conditions in snail kite nesting habitats, potentially increasing nest depredation.

\section{Heavy Precipitation Events Decrease Prey Access and Densities}

Rising and high water can affect future applesnail populations by inhibiting reproduction during flooding events (Darby and others, 2005) and destroying eggs (Turner, 1998; Burks and others, 2017). Florida applesnail reproduction peaks in April before precipitation volume typically increases in June (fig. 5) while non-native applesnail reproductive season 
A. Everglades National Park B. Lake Okeechobee

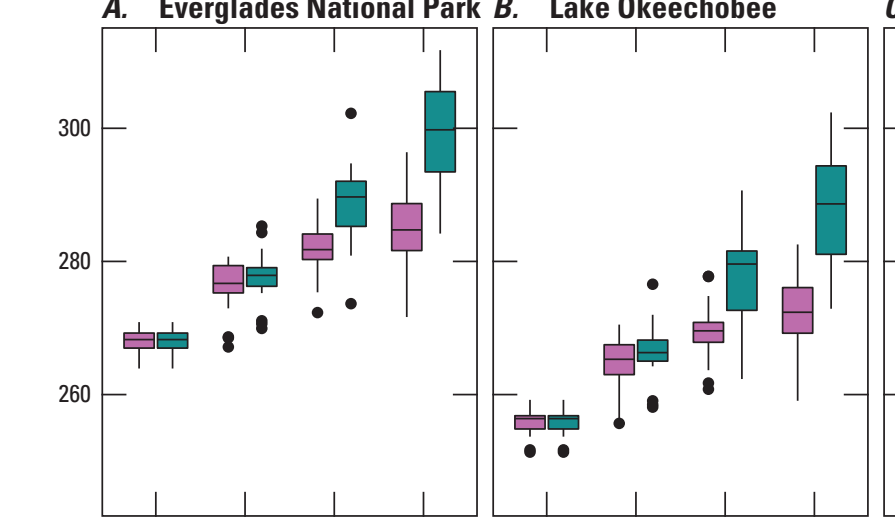

C. Kissimmee Chain of Lakes

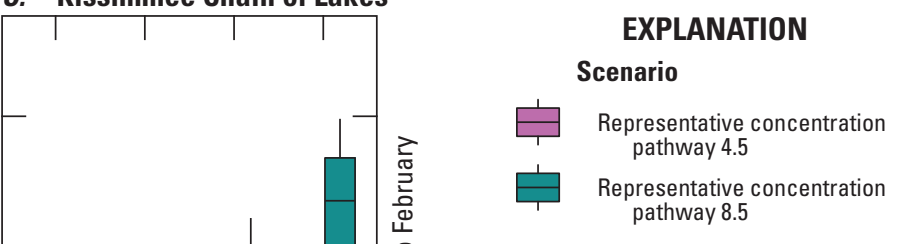

- Data point outside 1.5 times the interquartile range
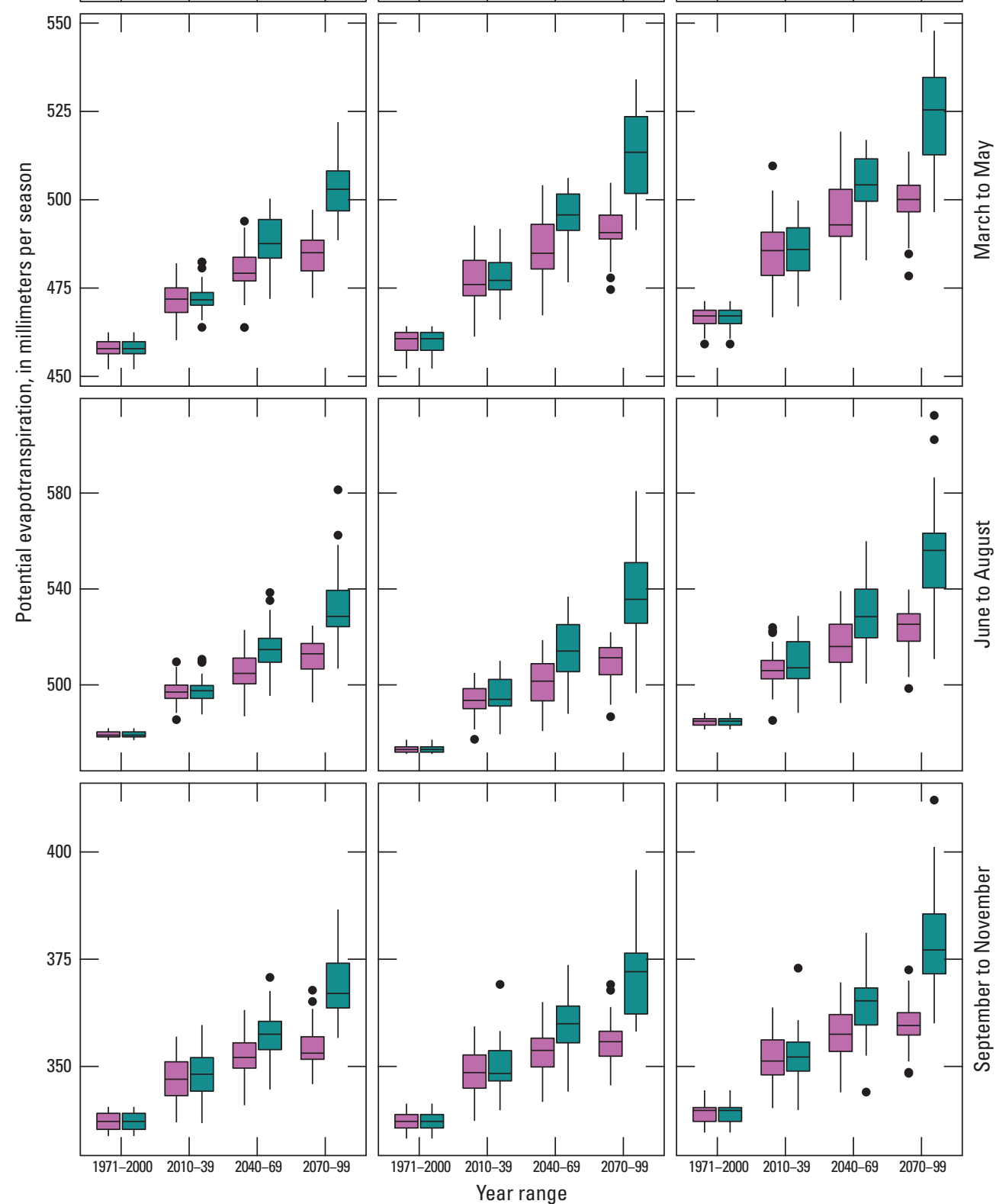

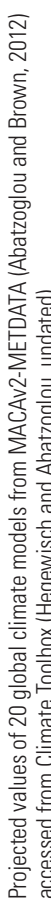

Figure 7. Projected seasonal potential evapotranspiration for four 30-year time periods from 1971 to 2099 in three areas in central and southern Florida used by nesting snail kites (Rostrhamus sociabilis plumbeus). $A$, Everglades National Park. $B$, Lake Okeechobee. $C$, Kissimmee Chain of Lakes. Potential evapotranspiration represents maximum water demand for a well-watered grass surface using Penman-Monteith method (Allen and others, 1998; Abatzoglou, 2013). Boxplots depict the minimum, first quartile, median, third quartile, and maximum, with outliers beyond 1.5 times the interquartile range depicted as single points. 
appears to last throughout the summer (Marzolf, 2015; Burks and others, 2017). Global climate models project spring seasons with similar overall volume of precipitation and summer months with decreasing seasonal precipitation volume (fig. 3). These seasonal averages do not capture extreme precipitation events that have been increasing and are projected to continue increasing in the next 80 years (Reidmiller and others, 2018). Heavy precipitation events associated with tropical storms may happen after most of the applesnail egg production is completed each year. The frequency of heavy precipitation events will likely increase, with implications for snail kite foraging and nest success. Whether future heavy precipitation events affect applesnail densities will depend on the timing in relation to applesnail life cycles.

\section{Habitat}

\section{Central Florida Lacustrine Nesting Areas Less Sensitive to Climate Change}

Environmental drought differentially affects the waterbodies used by snail kites. In the Everglades and Lake Okeechobee, nest survival appears to be particularly sensitive to recession and low water depth (Fletcher and others, 2021). Central Florida lacustrine systems, like the Kissimmee Chain of Lakes, are less susceptible to drought events (Reichert and others, 2016). The availability of non-native applesnails has opened new habitat for snail kites (Cattau and others, 2016); high water levels following Hurricane Irma in 2017 and the presence of non-native applesnails led to snail kite breeding range expanding more than 100 kilometers northward in the years following the storm (Poli and others, 2020). Central Florida lacustrine waterbodies are associated with lower adult survival rates, though the mechanism behind this relation is unclear (Cattau and others, 2016). Climate change will differentially affect snail kite nesting areas and could cause snail kites to disperse to new waterbodies.

\section{Rising Sea Level and Changing Climate Affect Habitat Suitability in the Everglades}

Snail kites primarily use inland habitats (Fletcher and others, 2020), which should be buffered from the direct effects of sea-level rise in Florida, except in the Everglades. The Everglades are at risk from sea-level rise and saltwater intrusion. The Everglades are currently less than 1.5 meters (m) above mean sea level (Obeysekera and others, 2015), putting them at great risk from projected sea-level rise of $0.3-1.3 \mathrm{~m}$ by 2100 . Sea-level rise could exceed these projections, rising as much as $2.5 \mathrm{~m}$ by 2100 (Reidmiller and others, 2018). The future state of the Everglades ecosystem is dependent not only on sea-level rise but also on freshwater inputs. The freshwater habitat used by snail kites in areas like Water Conservation
Area 3A in the Everglades is maintained by the combined inputs of freshwater inflow from more northern lakes and rivers through Lake Okeechobee and direct precipitation (Dessu and others, 2018). Projected increases in potential evapotranspiration (fig. 4), which may not be offset by concurrent increases in precipitation (fig. 2), will likely decrease the quality of surface flows into the Everglades (Obeysekera and others, 2015), decreasing habitat suitability for snail kites.

\section{Management}

\section{Potential for Water-Management Decisions to Offset or Exacerbate Changes in Water Levels}

Regional water levels are highly managed in south and central Florida. Climate projections indicate that warmer temperatures and associated increased evapotranspiration may increase the frequency of low water levels unless compensated for by increased rainfall. Changing climate will likely place new stresses on water management, especially in south Florida (Obeysekera and others, 2011). Changing precipitation, increasing temperature, and rising sea levels will require the incorporation of new scenarios into water-resource planning to accommodate changes in water budgets and water supply demands (Obeysekera and others, 2015; Mirchi and others, 2018). Water-management practices can change water levels rapidly, putting nests at risk (Fletcher and others, 2021). Increases in high and low water level events are likely under a changing climate; however, regional water-management actions can adjust the magnitude, timing, and speed of changing hydrologic conditions to manage some of the risk to snail kite populations.

\section{References Cited}

Abatzoglou, J.T., 2013, Development of gridded surface meteorological data for ecological applications and modelling: International Journal of Climatology, v. 33, no. 1, p. 121-131. [Also available at https://doi.org/10.1002/ joc.3413.]

Abatzoglou, J.T., and Brown, T.J., 2012, A comparison of statistical downscaling methods suited for wildfire applications: International Journal of Climatology, v. 32, no. 5, p. 772-780. [Also available at https://doi.org/10.1002/ joc.2312.]

Allen, R.G., Pereira, L.S., Raes, D., and Smith, M., 1998, Crop Evapotranspiration-Guidelines for Computing Crop Requirements: Rome, Italy, Irrigation and Drainage Paper No. 56, United Nations Food and Agricultural Organization. [Also available at http://www.fao.org/3/ x0490e/x0490e00.htm.] 
Beissinger, S., 1986, Demography, environmental uncertainty, and the evolution of mate desertion in the snail kite: Ecology, v. 67, no. 6, p. 1445-1459. [Also available at https://doi.org/10.2307/1939076.]

Beissinger, S.R., 1995, Modeling extinction in periodic environments-Everglades water levels and snail kite population viability: Ecological Applications, v. 5, no. 3, p. 618-631. [Also available at https://doi.org/10.2307/ 1941971.]

Beissinger, S.R., and Snyder, N.F.R., 2002, Water levels affect nest success of the snail kite in Florida-AIC and the omission of relevant candidate models: The Condor, v. 104, no. 1, p. 208-215. [Also available at https://doi.org/ 10.1093/condor/104.1.208.]

Burks, R.L., Bernatis, J., Byers, J.E., Carter, J., Martin, C.W., McDowell, W.G., and Van Dyke, J., 2017, Identity, reproductive potential, distribution, ecology and management of invasive Pomacea maculata in the southern United States, in Joshi, R.C., Cowie, R.H, and Sebastian, L.S., eds., Biology and management of invasive apple snails: Muñoz, Nueva Ecija Philippines, Philippine Rice Research Institute, p. 293-333. [Also available at https://www.cabi.org/ISC/ FullTextPDF/2017/20173354474.pdf.]

Cattau, C.E., Darby, P.C., Fletcher, R.J., Jr., and Kitchens, W.M., 2014, Reproductive responses of the endangered snail kite to variations in prey density: The Journal of Wildlife Management, v. 78, no. 4, p. 620-631. [Also available at https://doi.org/10.1002/jwmg.706.]

Cattau, C.E., Fletcher, R.J., Jr., Reichert, B.E., and Kitchens, W.M., 2016, Counteracting effects of a non-native prey on the demography of a native predator culminate in positive population growth: Ecological Applications, v. 26, no. 7, p. 1952-1968. [Also available at https://doi.org/10.1890/ 15-1020.1.]

Darby, P.C., Bennetts, R.E., and Karunaratne, L.B., 2006, Apple snail densities in habitats used by foraging snail kites: Florida Field Naturalist, v. 34, no. 2, p. 37-68.

Darby, P.C., Bennetts, R.E., Miller, S.J., and Percival, H.F., 2002, Movements of Florida apple snails in relation to water levels and drying events: Wetlands, v. 22, no. 3, p. 489-498.

Darby, P.C., Bennetts, R.E., and Percival, H.F., 2008, Dry down impacts on apple snail (Pomacea paludosa) demography-Implications for wetland water management: Wetlands, v. 28, no. 1, p. 204-214. [Also available at https://doi.org/10.1672/07-115.1.]

Darby, P.C., Karunaratne, L.B., and Bennetts, R.E., 2005, The influence of hydrology and associated habitat structure on spatial and temporal patterns of apple snail abundance and recruitment: Pensacola, Fla., University of West Florida, Final Report to U.S. Geological Survey.
Dessu, S.B., Price, R.M., Troxler, T.G., and Kominoski, J.S., 2018, Effects of sea-level rise and freshwater management on long-term water levels and water quality in the Florida Coastal Everglades: Journal of Environmental Management, v. 211, p. 164-176. [Also available at https://doi.org/ 10.1016/j.jenvman.2018.01.025.]

Dreitz, V.J., Bennetts, R.E., Toland, B., Kitchens, W.M., and Collopy, M.W., 2001, Spatial and temporal variability in nest success of snail kites in Florida-A meta-analysis: The Condor, v. 103, no. 3, p. 502-509. [Also available at https://doi.org/10.1093/condor/103.3.502.]

Fletcher, R.J., Poli, C.L., Jeffrey, B.M., Reichert, B.E., Potash, F., Robertson, E.P., and Gonzalez, A., 2020, Snail kite demography: 5 year final report and update on the 2019 breeding season: Gainesville, Fla., U.S. Geological Survey Biological Resource Division, Florida Cooperative Fish and Wildlife Research Unit, 138 p.

Fletcher, R.J., Robertson, E.P., Jeffrey, B.M., Poli, C.L., and Dudek, S., 2018, Snail kite demography—2018 Annual report on the 2017 breeding season: Gainseville, Fla., U.S. Geological Survey Biological Resource Division, Florida Cooperative Fish and Wildlife Research Unit, 91 p.

Fletcher, R.J., Jr., Robertson, E.P., Poli, C., Dudek, S., Gonzalez, A., and Jeffery, B., 2021, Conflicting nest survival thresholds across a wetland network alter management benchmarks for an endangered bird: Biological Conservation, v. 253, 9 p. [Also available at https://doi.org/10.1016/j.biocon.2020.108893.]

Glasheen, P.M., Calvo, C., Hayes, K.A., and Burks, R.L., 2017, Survival, recovery, and reproduction of apple snails (Pomacea spp.) following exposure to drought conditions: Freshwater Science, v. 36, no. 2, p. 316-324. [Also available at https://doi.org/10.1086/691791.]

Hegewisch, K.C., and Abatzoglou, J.T., undated, Climate toolbox-Future boxplots web tool: accessed May 26, 2021, at https://climatetoolbox.org/.

Kushlan, J.A., 1975, Population changes of apple snail, Pomacea paludosa, in the southern Everglades: Nautilus, v. 89, no. 1, p. 21-23.

Marzolf, N.S., 2015, Environmental limits on dispersal of invasive Pomacea maculata in Lake Seminole: Athens, Ga., University of Georgia, Master's Thesis, 98 p. [Also available at https://getd.libs.uga.edu/pdfs/marzolf_nicholas_s_ 201512_ms.pdf.]

Mirchi, A., Watkins, D.W., Engel, V., Sukop, M.C., Czajkowski, J., Bhat, M., Rehage, J., Letson, D., Takatsuka, Y., and Weisskoff, R., 2018, A hydro-economic model of South Florida water resources system: Science of the Total Environment, v. 628-629, p. 1531-1541. [Also available at https://doi.org/10.1016/j.scitotenv.2018.02.111.] 
Mooij, W.M., Bennetts, R.E., Kitchens, W.M., and DeAngelis, D.L., 2002, Exploring the effect of drought extent and interval on the Florida snail kite-Interplay between spatial and temporal scales: Ecological Modelling, v. 149, no. 1-2, p. 25-39. [Also available at https://doi.org/10.1016/S03043800(01)00512-9.]

Obeysekera, J., Barnes, J., and Nungesser, M., 2015, Climate sensitivity runs and regional hydrologic modeling for predicting the response of the greater Florida Everglades ecosystem to climate change: Environmental Management, v. 55, no. 4, p. 749-762. [Also available at https://doi.org/ 10.1007/s00267-014-0315-x.]

Obeysekera, J., Irizarry, M., Park, J., Barnes, J., and Dessalegne, T., 2011, Climate change and its implications for water resources management in south Florida: Stochastic Environmental Research and Risk Assessment, v. 25, no. 4, p. 495-516. [Also available at https://doi.org/ 10.1007/s00477-010-0418-8.]

Olbert, J.M., 2013, The breeding ecology of endangered snail kites (Rostrhamus sociabilis plumbeus) on a primary nesting site in Central Florida, USA: Gainsville, Fla., University of Florida, Master's Thesis, 135 p. [Also available at https://ufdc.ufl.edu/UFE0045445/00001.]

Palecki, M., Durre, I., Larimore, J., and Applequist, S., 2021, NOAA’s 1991-2020 climate normal: accessed July 6, 2021, at https://www.ncei.noaa.gov/access/search/data-search/ normals-monthly-1991-2020.

Poli, C.L., Dudek, S.J., Jeffrey, B.M., Robertson, E.P., and Fletcher, R.J., 2020, Recent breeding range expansion of the endangered snail kite (Rostrhamus sociabilis) in Florida: The Wilson Journal of Ornithology, v. 132, no. 1, p. 183-188. [Also available at https://doi.org/10.1676/15594491-132.1.183.]

Qiu, C., and Ciuca, V., 2021, South Florida hydrology and water management, chap. 2 of 2021 South Florida Environmental Report-Volume 1: South Florida Water Management District, p. 2-1-2-30. [Also available at https://apps.sfwmd.gov/sfwmd/SFER/2021_sfer_final/v1/ chapters/v1_ch2.pdf.]

Reichert, B.E., Fletcher, R.J., and Kitchens, W.M., 2021, The demographic contributions of connectivity versus local dynamics to population growth of an endangered bird: Journal of Animal Ecology, v. 90, no. 3, p. 574-584. [Also available at https://doi.org/10.1111/1365-2656.13387.]

Reichert, B.E., Kendall, W.L., Fletcher, R.J., and Kitchens, W.M., 2016, Spatio-temporal variation in age structure and abundance of the endangered snail kite-Pooling across regions masks a declining and aging population: PLoS ONE, v. 11, no. 9. [Also available at https://doi.org/10.1371/ journal.pone.0162690.]
Reichert, B.E., Martin, J., Kendall, W.L., Cattau, C.E., and Kitchens, W.M., 2010, Interactive effects of senescence and natural disturbance on the annual survival probabilities of snail kites: Oikos, v. 119, no. 6, p. 972-979. [Also available at https://doi.org/10.1111/j.1600-0706.2010.18366.x.]

Reidmiller, D.R., Avery, C.W., Easterling, D.R., Kunkel, K.E., Lewis, K.L.M., Maycock, T.K., and Stewart, B.C., 2018, Impacts, risks, and adaptation in the United States-The Fourth National Climate Assessment, Volume II:

U.S. Global Change Research Program, accessed August 19, 2021, at https://nca2018.globalchange.gov/.

Robertson, E.P., Fletcher, R.J., and Austin, J.D., 2017, The causes of dispersal and the cost of carry-over effects for an endangered bird in a dynamic wetland landscape: Journal of Animal Ecology, v. 86, no. 4, p. 857-865.

Runkle, J., Kunkel, K., Champion, S., Frankson, R., Stewart, B., and Sweet, W., 2017, Florida State climate summary: National Oceanic and Atmospheric Administration Technical Report NESDIS 149-FL, 4 p.

Snyder, N.F.R., Beissinger, S.R., and Chandler, R.E., 1989, Reproduction and demography of the Florida Everglade (snail) kite: The Condor, v. 91, no. 2, p. 300. [Also available at https://doi.org/10.2307/1368308.]

Turner, R.L., 1998, Effects of submergence on embryonic survival and developmental rate of the Florida applesnail, Pomacea paludosa-Implications for egg predation and marsh management: Florida Scientist, v. 61, no. 2, p. 118-129.

Wang, G., Kirchhoff, C.J., Seth, A., Abatzoglou, J.T., Livneh, B., Pierce, D.W., Fomenko, L., and Ding, T., 2020, Projected changes of precipitation characteristics depend on downscaling method and training data-MACA versus LOCA using the U.S. Northeast as an example: Journal of Hydrometeorology, v. 21, no. 12, p. 2739-2758. [Also available at https://doi.org/10.1175/JHM-D-19-0275.1.]

Winsberg, M.D., 2021, Climate of Florida: National Climate Data Center, National Oceanic and Atmospheric Administration, 12 p., accessed August 27, 2021, at https://climatecenter.fsu.edu/images/fcc/ climateofflorida.pdf.

Wootten, A.M., Dixon, K.W., Adams-Smith, D.J., and McPherson, R.A., 2021, Statistically downscaled precipitation sensitivity to gridded observation data and downscaling technique: International Journal of Climatology, v. 41, no. 2, p. 980-1001. [Also available at https://doi.org/10.1002/ joc.6716.] 
Manuscript approved on October 30th, 2021.

For additional information, contact:

Director,

Midwest Climate Adaptation Science Center

1954 Buford Avenue

St Paul, MN 55108

612-437-9769

For additional information, visit: https://www.usgs.gov/programs/ climate-adaptation-science-centers/midwest-casc.

Publishing support provided by the Indianapolis and Rolla Publishing Service Centers 

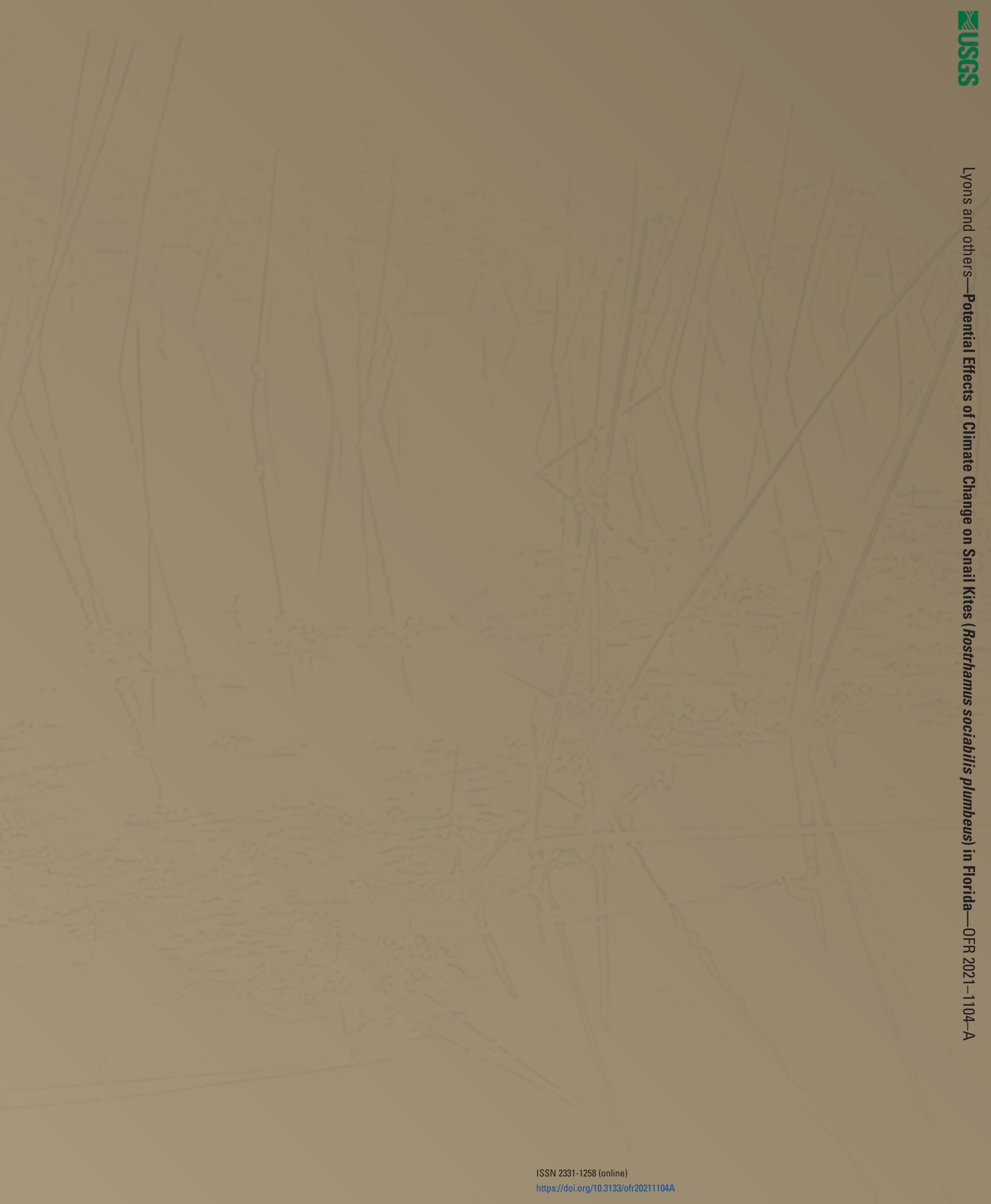